\title{
PENINGKATAN KOMPETENSI GURU MENERAPKAN MODEL PEMBELAJARAN PROBLEM BASED LEARNING (PBL) MELALUI WORKSHOP BAGI GURU MATA PELAJARAN KELAS IX DI UPT SMP NEGERI 20 MEDAN
}

\author{
Oleh: \\ Halpan Siregar
}

\begin{abstract}
ABSTRAK
Penelitian Tindakan Sekolah ini dilakukan melalui workshop yang bertujuan untuk Peningkatan Kompetensi Guru Menerapkan Model Pembelajaran Problem Based Learning (PBL) Melalui Workshop Bagi Guru Mata Pelajaran Kelas IX di UPT SMP Negeri 20 Medan Tahun Pelajaran 2018/2019 pada Semester Ganjil, dengan subjek penelitian berjumlah 13 orang. Metode yang digunakan adalah desain penelitian Tindakan Sekolah. Masing-masing melalui tahap perencanaan, tindakan, observasi/evaluasi dan refleksi. Hasil penelitian menunjukkan bahwa melalui workshop dapat meningkatkan kompetensi guru untuk Menerapkan Model Pembelajaran Problem Based Learning (PBL). Berdasarkan hasil dan pembahasan diatas, ada beberapa kesimpulan yang dapat disimpulkan dalam penelitian ini: 1).Kompetensi Guru menerapkan Model Pembelajaran Problem Based Learning (PBL) Melalui Workshop Bagi Guru Mata Pelajaran Kelas IX di UPT SMP Negeri 20 Medan meningkat setelah mengikuti Workshop. 2).Nilai rata-rata kompetensi guru kelas IX menerapkan Model Pembelajaran Problem Based Learning (PBL) siklus 1 adalah 28,08 (kurang). 3). Nilai rata-rata kompetensi guru kelas IX Menerapkan Model Pembelajaran Problem Based Learning (PBL) siklus 2 adalah 55,38\% (cukup). 4). Nilai rata-rata kompetensi guru kelas VIII menerapkan Model Pembelajaran Problem Based Learning (PBL)siklus 3 adalah 84,31 (sangat baik). 5). Nilai rata-rata kompetensi guru kelas IX dalam menerapkan Model Pembelajaran Problem Based Learning (PBL) meningkat dari siklus 1 ke siklus 3 yaitu: 28,08 menjadi 84,31. Peningkatan nilai rata-rata kompetensi guru: $84,31 \%-28,08 \%=56,23 \%$. 6). Nilai sikap Guru UPT SMP Negeri 20 Medan 98,46\% (sagat setuju) dan konsisten menerapkan Model Pembelajaran Problem Based Learning (PBL) melalui workshop yang dilakukan oleh peneliti, kerena kompetensi mereka meningkat.
\end{abstract}

Kata Kunci: Kompetensi Guru, Model Pembelajaran Problem Based Learning (PBL), Workshop

\section{A. Pendahuluan}

Guru merupakan salah satu komponen penting dalam pendidikan, oleh karena itu, sudah selayaknya guru mempunyai kompetensi yang berkaitan dengan tugas dan tanggung jawabnya, salah satunya adalah guru dituntut memiliki wawasan yang luas tentang penggunaan strategi pembelajaran yang bervariasi dan menarik bagi siswa untuk meningkatkan hasil belajar siswa. Selain masalah di atas, mutu pendidikan di Indonesia juga rendah khususnya pada pendidikan dasar dan menengah. Salah satunya disebabkan oleh dominannya penerapan metode pengajaran konvensional, yang menitik beratkan guru sebagai sumber informasi dalam jumlah yang besar (Dasna, 2007). Metode konvensional juga sudah banyak dikritik dan dituntut untuk diperbaiki, karena sifatnya satu arah yaitu dari guru ke siswa (teacher centered) sehingga siswa hanya pasif menerima materi dari guru. Selama ini guru kurang memberikan perhatian Problem Based Learning (PBL) di UPT SMP cenderung diarahkan semata-mata untuk menyiapkan anak didik melanjutkan pendidikan ke jenjang yang lebih tinggi. 
Journal of Education and Teaching Learning (JETL) 2019

Vol. 1, No. 3, 41-55

Journal Homepage: http://pusdikra-publishing.com/index.php/jetl

Berdasarkan data hasil supervisi yang dilakukan oleh peneliti selaku Kepala Sekolah pada UPT SMP Negeri 20 Medan diperoleh data awal: 100\% guru mata pelajaran kelas IX melakukan proses belajar mengajar secara konvensional, materi pelajaran disampaikan secara verbal padahal materi pelajaran harus diajarkan dengan melibatkan siswa. 100\% guru mata pelajaran kelas IX belum memahami cara menerapkan model pembelajaran Problem Based Learning (PBL).

Model pembelajaran Problem Based Learning (PBL) memiliki beberapa kelebihan/keunggulan yaitu : (1) merupakan teknik yang cukup bagus memahami isi pelajaran, (2) dapat menantang kemampuan siswa serta memberikan kepuasan untuk menentukan pengetahuan baru bagi siswa, (3) dapat meningkatkan aktivitas pembelajaran siswa, (4) dapat membantu siswa bagaimana mentransfer pengetahuan mereka untuk memahami masalah dalam kehidupan nyata, (5) dapat membantu siswa untuk mengembangkan pengetahuan barunya dan bertanggung jawab dalam pembelajaran yang mereka lakukan, (6) dapat mendorong siswa untuk melakukan evaluasi sendiri baik terhadap hasil maupun proses belajarnya, (7) dapat mengembangkan kemampuan siswa untuk berpikir kritis dan mengembangkan kemampuan mereka untuk menyesuaikan dengan pengetahuan baru, (8) dapat memberikan kesempatan kepada siswa untuk mengaplikasikan pengetahuan yang mereka miliki dalam dunia nyata, (9) dapat mengembangkan minat siswa untuk secara terus-menerus belajar sekalipun belajar pada pendidikan formal yang telah berakhir ( Sanjaya, 2006).

Penerapan model pembelajaran Problem Based Learning (PBL) ini pernah diteliti oleh Sembiring (2009), dari hasil penelitian yang dilakukan terjadi peningkatan hasil belajar siswa sebesar $29,00 \%$ dan peningkatan aktivitas siswa sebesar 30,30\%. Berdasarkan temuan dari penelitian tersebut, maka peneliti selaku Kepala Sekolah pada UPT SMP Negeri 20 Medan ingin membina guru agar mereka dapat menerapkan model pembelajaran Problem Based Learning (PBL).

Sesuai dengan keadaan guru di UPT SMP Negeri 20 Medan tersebut, maka perlu dilakukan Penelitian Tindak Sekolah (PTS) dengan judul: "PENINGKATAN KOMPETENSI GURU MENERAPKAN MODEL PEMBELAJARAN PROBLEM BASED LEARNING (PBL) MELALUI WORKSHOP BAGI GURU MATA PELAJARAN KELAS IX DI UPT SMP NEGERI 20 MEDAN".

Berdasarkan latar belakang masalah tersebut, maka identifikasi masalahnya adalah sebagai berikut 1). Siswa UPT SMP Negeri 20 Medan kurang melakukan kerja sama dalam kegiatan belajar. 2). Guru-guru UPT SMP Negeri 20 Medan kurang melibatkan siswa dalam kegiatan belajar secara kelompok. 3). Guru-guru UPT SMP Negeri 20 Medan belum memahami cara menerapkan model 
Journal of Education and Teaching Learning (JETL) 2019

Vol. 1, No. 3, 41-55

Journal Homepage: http://pusdikra-publishing.com/index.php/jetl

pembelajaran Problem Based Learning (PBL). Berdasarkan identifikasi masalah tersebut, maka masalah penelitian ini dapat dirumuskan sebagai berikut: Bagaimana upaya meningkatkan kompetensi guru menerapkan model pembelajaran Problem Based Learning (PBL) melalui workshop bagi guru mata pelajaran kelas IX di UPT SMP Negeri 20 Medan? Tujuan penelitian ini adalah untuk menemukan strategi peningkatan kompetensi guru menerapkan model pembelajaran Problem Based Learning (PBL) melalui workshop bagi guru mata pelajaran kelas IX di UPT SMP Negeri 20 Medan. Manfaat penelitian ini adalah: 1). Bagi Peneliti. Dengan melakukan Penelitian Tindakan Sekolah (PTS) ini, maka peneliti akan dapat menemukan strategi peningkatan kompetensi guru menerapkan model pembelajaran Problem Based Learning (PBL) melalui workshop bagi guru mata pelajaran kelas IX di UPT SMP Negeri 20 Medan. 2). Bagi Guru. Dengan adanya Penelitian Tindakan Sekolah (PTS) yang dilakukan oleh peneliti, maka guru-guru akan meningkat kompetensinya dalam menerapkan model pembelajaran Problem Based Learning (PBL). Dengan demikian guru dapat meningkatkan kualitas belajar mengajar, sehingga siswa dapat lebih dilibatkan dalam pembelajaran. 3). Bagi Siswa. Penelitian ini akan mengaktifkan siswa melakukan pemecahan masalah. Hipotesis tindakan pada penelitian ini adalah: Kompetensi guru mata pelajaran kelas IX di UPT SMP Negeri 20 Medan menerapkan model pembelajaran Problem Based Learning (PBL) dapat meningkat melalui workshop.

Guza (2008:411-417) mengatakan bahwa standar kompetensi guru meliputi empat kompetensi utama, yaitu (1) kompetensi pedagogik, (2) kompetensi kepribadian, (3) kompetensi sosial, dan (4) kompetensi profesional. Jika diperhatikan kompetensi guru tersebut ternyata kompetensi yang harus dimiliki oleh guru mempunyai hubungan yang saling berkaitan agar terwujud kompetensi guru yang optimal. Menurut Sanjaya (2008:131) kompetensi adalah perpaduan dari pengetahuan, keterampilan, nilai dan sikap yang direfleksikan dalam kebiasaan berpikir dan bertindak. Seseorang yang telah memiliki kompetensi dalam bidang tertentu bukan hanya mengetahui, akan tetapi juga dapat memahami dan menghayati bidang tersebut yang tercermin dalam pola perilaku sehari-hari.

Menurut Suprijanto (2008:79) workshop adalah pertemuan orang yang bekerja sama dalam kelompok kecil, biasanya dibatasi pada masalah yang berasal dari mereka sendiri. Peran serta diharapkan untuk dapat menghasilkan produk tertentu. Sedangkan menurut Soeharto (2005:36-37) bahwa workshop adalah pertemuan khusus yang dihadiri sekelompok manusia yang bergerak dalam lingkungan bidang kerja yang sejenis. Menurut Zaini (2002:12) bahwa workshop dirancang untuk 
Journal of Education and Teaching Learning (JETL) 2019

Vol. 1, No. 3, 41-55

Journal Homepage: http://pusdikra-publishing.com/index.php/jetl

para guru di sekolah, hal itu berdasarkan pada pertimbangan bahwa materi dan strategi yang diajarkan dalam workshop disesuaikan dengan pendidikan untuk orang dewasa. Workshop ini menggunakan pendekatan andragogi. Hal itu dimaksudkan agar pola pembelajaran di kelas dapat berlangsung secara partisipatif, variatif dan interaktif, sesuai dengan pengalaman masing-masing peserta. Berbagai pengalaman yang digali dari para peserta akan dijadikan sumber inspirasi, manakala para peserta diajak untuk berdiskusi berdasarkan pada pengalaman.

Model pembelajaran berbasis masalah (Problem Based Learning (PBL) disingkat PBL, merupakan salah satu model pembelajarn inovatif yang dapat memberikan kondisi belajar aktif kepada siswa. PBL telah dikenal sejak zaman Jhon Dewey yang sekarang ini mulai diangkat sebab di tinjau secara umum pembelajaran Problem Based Learning (PBL) terdiri dari menyajikan kepada siswa situasi masalah yang autentik dan bermakna yang dapat memberi kemudahan kepada mereka untuk melakukan penyelidikan dan inkuiri. PBL merupakan satu proses pembelajaran dimana masalah merupakan pemandu utama ke arah pembelajaran tersebut. PBL adalah metode pendidikan yang mendorong siswa untuk mengenal cara belajar dan bekerja sama dalamt kelompok untuk mencari penyelesaian masalah-masalah di dunia nyata. Simulasi masalah digunakan untuk mengaktifkan keingintahuan siswa sebelum mulai mempelajari suatu subyek. PBL, menyiapkan siswa untuk berpikir secara kritis dan analitis, serta mampu untuk mendapatkan dan menggunakan secara tepat sumber-sumber pembelajaran. Dengan menggunakan pendekatan PBL ini, siswa akan bekerja secara kooperatif untuk menyelesaikan masalah sebenarnya dan yang paling penting membina kemahiran untuk menjadi siswa yang boleh belajar secara mandiri (Riyanto, 2008). Tujuan Pembelajaran Problem Based Learning (PBL) adalah 1). Membantu guru memberikan informasi sebanyak-banyaknva kepada peserta didik. 2). Membantu peserta didik mengembangkan kemampuan berpikir, pemecahan masalah, dan keterampilan intelektual. 3). Belajar tentang berbagai peran orang dewasa, melalui pelibatan mereka dalam pengalaman nyata atau simulasi. 4). Menjadi pembelajar yang mandiri.

\section{Tabel 2.1 Sintaks Pembelajaran Problem Based Learning (PBL)}

\begin{tabular}{|l|l|}
\hline \multicolumn{1}{|c|}{ Fase } & \multicolumn{1}{c|}{ Kegiatan Guru } \\
\hline $\begin{array}{l}\text { Fase 1 } \\
\text { Orientasi Siswa pada masalah }\end{array}$ & $\begin{array}{l}\text { Guru menjelaskan tujuan pembelajaran, menjelaskan suatu } \\
\text { yang dibutuhkan, memotivasi siswa terlibat pada aktivitas } \\
\text { pemecahan masalah yang dipilihnya. }\end{array}$ \\
\hline $\begin{array}{l}\text { Fase 2 } \\
\text { Mengorganisasikan siswa untuk belajar }\end{array}$ & $\begin{array}{l}\text { Guru membimbing siswa mendefenisikan dan } \\
\text { mengorganisasikan tugas belajar yang berhubungan dengan } \\
\text { masalah tersebut }\end{array}$ \\
\hline
\end{tabular}


Journal of Education and Teaching Learning (JETL) 2019

Vol. 1, No. 3, 41-55

Journal Homepage: http://pusdikra-publishing.com/index.php/jetl

\begin{tabular}{|l|l|}
\hline $\begin{array}{l}\text { Fase 3 } \\
\text { Menbimbing penyelidikan individu maupun } \\
\text { kelompok }\end{array}$ & $\begin{array}{l}\text { Guru membimbing siswa mengumpulkan informasi yang } \\
\text { sesuai, melaksanakan eksperimen untuk mendapatkan } \\
\text { penjelasan dan pemecahan masalah }\end{array}$ \\
\hline $\begin{array}{l}\text { Fase } \mathbf{4} \\
\begin{array}{l}\text { Mengembangkan karya dan menyajikan } \\
\text { hasil }\end{array}\end{array}$ & $\begin{array}{l}\text { Guru membimbing siswa merencanakan dan menyiapkan } \\
\text { karya yang sesuai seperti laporan dan hasil karya }\end{array}$ \\
\hline $\begin{array}{l}\text { Fase } \mathbf{5} \\
\begin{array}{l}\text { Menganalisis dan menevaluasi proses } \\
\text { pemecagan masalah }\end{array}\end{array}$ & $\begin{array}{l}\text { Guru membimbing siswa melakukan refleksi dan evaluasi } \\
\text { terhadap penyelidikan dan proses yang mereka gunakan }\end{array}$ \\
\hline
\end{tabular}

\section{B. Metodologi Penelitian}

Lokasi penelitian ini dilaksanakan di UPT SMP Negeri 20 Medan yang berlokasi di Jl. Kapten Rahmad Buddin Kel. Terjun Kec. Medan Marelan. Waktu penelitian ini dilaksanakan selama 5 bulan yaitu bulan Agustus 2019 sampai dengan Desember 2019. Subyek penelitian adalah guru mata pelajaran kelas IX pada Workshop bagi guru mata pelajaran kelas IX UPT SMP Negeri 20 Medan sebanyak 13 (tiga belas) orang, terdiri dari 1 (satu) orang dari setiap mata pelajaran. Obyek penelitian adalah model pembelajaran Problem Based Learning (PBL). Untuk menerapkan model pembelajaran Problem Based Learning (PBL) pada pembelajaran maka setiap guru mata pelajaran kelas IX SMP memetakan materi pelajaran yang diajarkan secara pemecahan masalah dilakukan melalui Workshop bagi guru mata pelajaran kelas IX Pola MPR.

Model yang digunakan dalam workshop ini adalah Model Kemmis yang dirancang dengan proses siklus (cyclical) yang terdiri dati 4 (empat) fase kegiatan yaitu: merencanakan (planning), melakukan tindakan (action), mengamati (observation), dan merefleksi (reflectif).

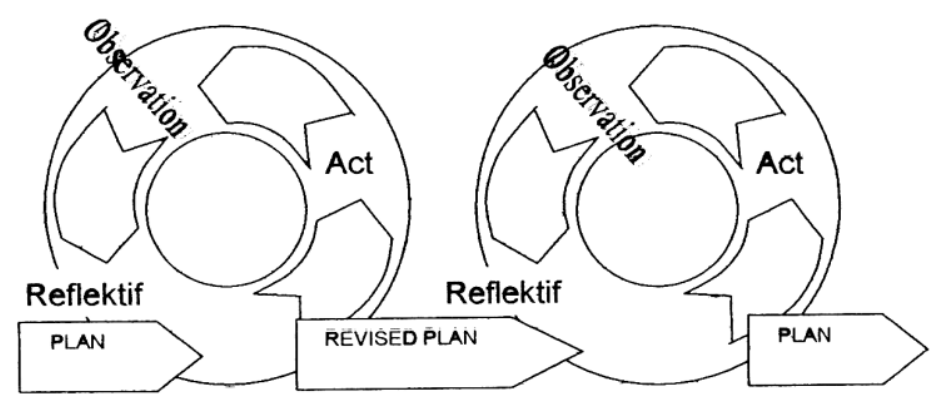

(Sumber: Kemmis dalam Sukardi 2005) Gambar 1 Siklus Model Kemmis

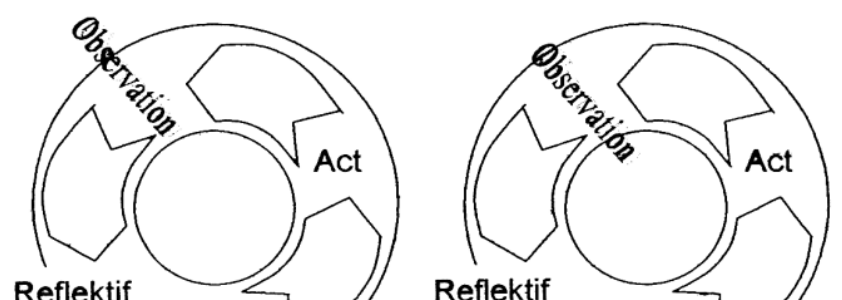


Journal of Education and Teaching Learning (JETL) 2019

Vol. 1, No. 3, 41-55

Journal Homepage: http://pusdikra-publishing.com/index.php/jetl

\section{a. Siklus 1}

Pada tahap perencanaan siklus 1 Workshop bagi guru mata pelajaran kelas IX ini, peneliti beserta kepala sekolah dan semua guru mata pelajaran kelas IX yang tergabung pada Workshop bagi guru mata pelajaran kelas IX UPT SMP Negeri 20 Medan yang berlokasi pada UPT SMP Negeri 20 Medan untuk mengikuti pertemuan workshop bagi guru mata pelajaran kelas IX yang dilaksanakan oleh peneliti. Peneliti merencanakan Workshop bagi guru mata pelajaran kelas IX dengan cara Modelling. Agar para guru mata pelajaran kelas IX pada Workshop bagi guru mata pelajaran kelas IX UPT SMP Negeri 20 Medan mudah memahami cara menerapkan model pembelajaran Problem Based Learning (PBL) cara Modelling maka peneliti menjadi model untuk memberikan contoh.

Peneliti menyajikan materi pembelajaran dengan menerapkan model pembelajaran Problem Based Learning (PBL yang dipaparkan pada saat pelaksanaan workshop bagi guru mata pelajaran kelas IX. Peneliti berkolaborasi dengan pengawas sekolah yang bertugas di UPT SMP Negeri 20 Medan. Peneliti menanya masing-masing guru secara bergiliran tentang apa yang sudah dipahami dan yang belum dipahaminya tentang penerapan model pembelajaran Problem Based Learning (PBL), dan memberikan kesempatan kepada pengawas sekolah untuk mengomentari apa yang sudah bagus dan apa kekurangan dari penguasaan guru tentang model pembelajaran Problem Based Learning (PBL). Mencatat semua pelaksanaan Modelling menerapkan model pembelajaran Problem Based Learning (PBL).

Peneliti bersama Pengawas Sekolah melakukan observasi pada siklus 1 ini tentang: (a) kemampuan guru meniru cara menjelaskan orientasi siswa pada masalah $=\ldots \%$ (...), (b) kemampuan guru meniru cara mengorganisasikan siswa untuk belajar $=\ldots \%(\ldots)$, (c) kemampuan guru meniru cara membimbing penyelidikan individu maupun kelompok $=\ldots \%$ (...), (d) kemampuan guru meniru cara mengembangkan karya dan menyajikan hasil $=\ldots \%(\ldots)$, dan (e) kemampuan guru meniru cara menganalisis dan mengevaluasi proses pemecahan masalah $=\ldots \%$ (...). Hasil observasi dianalisis oleh peneliti bersama pengawas sekolah sehingga didapat nilai masing-masing guru pada pertemuan 1 (Modelling) ini. Pada tahap refleksi siklus 1 Workshop bagi guru mata pelajaran kelas IX ini, peneliti bersama pengawas sekolah melakukan refleksi terhadap hasil observasi mengamati keseriusan guru mata pelajaran kelas IX mengikuti pembelajaran yang dilakukan oleh peneliti dengan cara Modelling.

Penilaian kompetensi guru menerapkan model pembelajaran Problem Based Learning 
Journal of Education and Teaching Learning (JETL) 2019

Vol. 1, No. 3, 41-55

Journal Homepage: http://pusdikra-publishing.com/index.php/jetl

(PBL) menggunakan instrumen observasi. Pada instrumen observasi penilaian kompetensi menerapkan model pembelajaran Problem Based Learning (PBL) tersebut ada 5 (lima) aspek penilaian, masing-masing aspek penilaian skornya 5 (lima), maka skor maksimal adalah 25 (dua puluh lima). Sedangkan skor perolehan bergantung kepada jumlah jawaban dari kelima aspek penilaian tersebut. Nilai dapat dihitung dengan menggunakan rumus:

$$
\begin{aligned}
\text { Nilai } & =\frac{\text { Skor perolehan }}{\text { Skor maksimal }} \times 100 \% \\
\text { Nilai } & =\frac{\text { Skor perolehan }}{* 100 \%}
\end{aligned}
$$

Penilaian kompetensi guru menerapkan model pembelajaran Problem Based Learning (PBL) sebagai berikut:

Tabel 3.1. Instrumen Penilaian Modelling Menerapkan Model Pembelajaran Problem Based Learning (PBL)

\begin{tabular}{|l|c|}
\hline \multicolumn{1}{|c|}{ Aspek Penilaian } & Rentang Skor \\
\hline $\begin{array}{l}\text { 1. Kemampuan guru meniru cara menjelaskan orientasi } \\
\text { siswa pada masalah }\end{array}$ & $1-5$ \\
\hline $\begin{array}{l}\text { 2. Kemampuan guru meniru cara mengorganisasikan } \\
\text { siswa untuk belajar }\end{array}$ & $1-5$ \\
\hline $\begin{array}{l}\text { 3. Kemampuan guru meniru cara membimbing } \\
\text { penyelidikan individu maupun kelompok }\end{array}$ & $1-5$ \\
\hline $\begin{array}{l}\text { 4. Kemampuan guru meniru cara mengembangkan karya } \\
\text { dan menyajikan hasil }\end{array}$ & $1-5$ \\
\hline $\begin{array}{l}\text { 5. Kemampuan guru meniru cara menganalisis dan } \\
\text { mengevaluasi proses pemecahan masalah }\end{array}$ & $1-5$ \\
\hline
\end{tabular}

Tabel 3.2. Penilaian Peer Teaching maupun Real Teaching Menerapkan Model Pembelajaran Problem Based Learning (PBL)

\begin{tabular}{|l|c|}
\hline \multicolumn{1}{|c|}{ Aspek Penilaian } & Rentang Skor \\
\hline $\begin{array}{l}\text { 1. Kemampuan guru menjelaskan orientasi } \\
\text { siswa pada masalah }\end{array}$ & $1-5$ \\
\hline $\begin{array}{l}\text { 2. Kemampuan guru mengorganisasikan } \\
\text { siswa untuk belajar }\end{array}$ & $1-5$ \\
\hline $\begin{array}{l}\text { 3. Kemampuan guru membimbing } \\
\text { penyelidikan individu maupun kelompok }\end{array}$ & $1-5$ \\
\hline
\end{tabular}


Journal of Education and Teaching Learning (JETL) 2019

Vol. 1, No. 3, 41-55

Journal Homepage: http://pusdikra-publishing.com/index.php/jetl

\begin{tabular}{|l|c|}
\hline $\begin{array}{l}\text { 4. Kemampuan guru mengembangkan karya } \\
\text { dan menyajikan hasil }\end{array}$ & $1-5$ \\
\hline $\begin{array}{l}\text { 5. Kemampuan guru menganalisis dan } \\
\text { mengevaluasi proses pemecahan masalah }\end{array}$ & $1-5$ \\
\hline
\end{tabular}

1. Penentuan nilai Modelling, Peer Teaching maupun Real Teaching menerapkan model pembelajaran Problem Based Learning (PBL)

\begin{tabular}{|l|}
\hline \multicolumn{1}{|c|}{ Nilai } \\
\hline $81-100=$ Sangat Baik \\
\hline $61-80=$ Baik \\
\hline $41-60=$ Cukup \\
\hline $21-40=$ Kurang \\
\hline $1-20$ = Sangat Kurang \\
\hline
\end{tabular}

Dengan cara penggunaan rumus yang sama dapat dihitung nilai kompetensi guru menerapkan model pembelajaran Problem Based Learning (PBL). Nilai kompetensi masing-masing guru menerapkan model pembelajaran Problem Based Learning (PBL adalah nilai pada siklus 1 (Modelling).

Nilai kompetensi masing-masing guru menerapkan model pembelajaran Problem Based Learning (PBL) adalah nilai pada siklus 2 (Peer Teaching).

Nilai kompetensi masing-masing guru menerapkan model pembelajaran Problem Based Learning (PBL) adalah nilai pada siklus 3 (Real Teaching).

2) Penilaian sikap guru menerapkan model pembelajaran Problem Based Learning (PBL).

Ada 4 (empat) aspek sikap, masing-masing aspek sikap skornya 5 (lima), maka skor maksimal adalah 20 (dua puluh). Sedangkan skor perolehan bergantung kepada jumlah jawaban dari kelima aspek sikap tersebut. Nilai dapat dihitung dengan menggunakan rumus:

$$
\begin{aligned}
\text { Nilai }= & \frac{\text { Skor perolehan }}{\text { Skor maksimal }} \times 100 \% \\
\text { Nilai }= & \frac{\text { Skor perolehan }}{20} \times 100 \%
\end{aligned}
$$

Penilaian sikap guru menerapkan model pembelajaran Problem Based Learning (PBL):

\section{Aspek Sikap:}

1. Menarik untuk dilakukan 
Journal of Education and Teaching Learning (JETL) 2019

Vol. 1, No. 3, 41-55

Journal Homepage: http://pusdikra-publishing.com/index.php/jetl

2. Mudah melakukannya

3. Menyenangkan

4. Termotivasi untuk menerapkan model pembelajaran Problem Based Learning (PBL) pada berbagai Kompetensi Dasar IPA.

\section{Skor:}

$5=$ SS $=$ Sangat Setuju

$4=S=$ Setuju

$3=\mathrm{KS}=$ Kurang Setuju

$2=$ TS $=$ Tidak Setuju

$1=$ STS $=$ Sangat Tidak Setuju

Banyaknya guru yang ikut Workshop bagi guru mata pelajaran kelas IX UPT SMP Negeri 20 Medan ada 13 (tiga belas) orang, maka nilai sikap adalah rata-rata nilai dari tiga belas orang guru tersebut.

\section{Hasil Penelitian dan Pembahasan}

Deskripsi hasil penelitian diuraikan dalam tahapan berupa siklus-siklus kegiatan. Pada penelitian ini kegiatan dilakukan dalam 3 (tiga) siklus sebagaimana berikut ini.

Data hasil observasi kompetensi guru mata pelajaran kelas IX menerapkan model pembelajaran Problem Based Learning (PBL pada Siklus 1 (Modelling), dari 13 (tiga belas) orang guru Workshop bagi guru mata pelajaran kelas IX UPT SMP Negeri 20 Medan adalah seperti tabel 1 berikut:

Tabel 1. Data Kompetensi Guru Mata Pelajaran Kelas IX Menerapkan Model Pembelajaran Problem Based Learning (PBL) Pada Siklus 1 (Modelling)

\begin{tabular}{|c|c|c|c|c|c|c|c|c|}
\hline \multirow{2}{*}{ No. } & \multicolumn{5}{|c|}{ Aspek Penilaian } & \multirow{2}{*}{ Jlh } & \multirow{2}{*}{ Nilai } & \multirow{2}{*}{ Keterangan } \\
\hline & 1 & 2 & 3 & 4 & 5 & & & \\
\hline 1 & 1 & 2 & 1 & 2 & 1 & 7 & 35 & Kurang \\
\hline 2 & 1 & 1 & 1 & 1 & 1 & 5 & 25 & Kurang \\
\hline 3 & 1 & 2 & 1 & 2 & 1 & 7 & 35 & Kurang \\
\hline 4 & 1 & 1 & 1 & 1 & 1 & 5 & 25 & Kurang \\
\hline 5 & 1 & 1 & 1 & 1 & 1 & 5 & 25 & Kurang \\
\hline 6 & 1 & 1 & 1 & 1 & 1 & 5 & 25 & Kurang \\
\hline 7 & 1 & 1 & 1 & 1 & 1 & 5 & 25 & Kurang \\
\hline 8 & 1 & 1 & 1 & 1 & 1 & 5 & 25 & Kurang \\
\hline 9 & 1 & 1 & 1 & 1 & 1 & 5 & 25 & Kurang \\
\hline 10 & 1 & 1 & 1 & 1 & 1 & 5 & 25 & Kurang \\
\hline 11 & 1 & 1 & 1 & 1 & 1 & 5 & 25 & Kurang \\
\hline 12 & 1 & 2 & 1 & 2 & 1 & 7 & 35 & Kurang \\
\hline 13 & 1 & 2 & 1 & 2 & 1 & 7 & 35 & Kurang \\
\hline
\end{tabular}


Journal of Education and Teaching Learning (JETL) 2019

Vol. 1, No. 3, 41-55

Journal Homepage: http://pusdikra-publishing.com/index.php/jetl

\begin{tabular}{|c|c|c|c|c|c|c|c|c|}
\hline ال & 13 & 17 & 13 & 17 & 13 & - & - & \\
\hline $\mathbf{N}$ & 20,00 & 26,15 & 20,00 & 26,15 & 20,00 & - & - & \\
\hline \multicolumn{7}{|c|}{ Jumlah Nilai } & 365 & \\
\hline \multicolumn{7}{|c|}{ Nilai Rata-rata } & 28,08 & Kurang \\
\hline
\end{tabular}

Pada tahap pelaksanaan siklus 1 dari hasil observasi kompetensi guru mata pelajaran kelas IX menerapkan model pembelajaran Problem Based Learning (PBL) pada siklus 1 (Modelling), dari 13 (tiga belas) orang guru Workshop bagi guru mata pelajaran kelas IX UPT SMP Negeri 20 Medan peserta workshop adalah: (a) kemampuan guru meniru cara menjelaskan orientasi siswa pada masalah $=20,00 \%$ (sangat kurang), (b) kemampuan guru meniru cara mengorganisasikan siswa untuk belajar $=26,15 \%$ (kurang), $\quad$ (c) kemampuan guru meniru cara membimbing penyelidikan individu maupun kelompok $=20,00 \%$ (sangat kurang), (d) kemampuan guru meniru cara mengembangkan karya dan menyajikan hasil $=26,15 \%$ (kurang), dan (e) kemampuan guru meniru cara menganalisis dan mengevaluasi proses pemecahan masalah $=20,00 \%$ (sangat kurang), maka perlu dilanjutkan ke siklus 2.

Siklus 2 Peneliti melaksanakan Workshop bagi guru mata pelajaran kelas IX dengan cara Peer Teaching. Peneliti menyuruh guru secara bergiliran untuk melakukan Peer Teaching menerapkan model pembelajaran Problem Based Learning (PBLsesuai dengan materi pelajaran yang diajarkan secara problem.

Data hasil observasi kompetensi guru mata pelajaran kelas IX model pembelajaran Problem Based Learning (PBL) pada siklus 2 (Peer Teaching), dari 13 (tiga belas) orang guru Workshop bagi guru mata pelajaran kelas IX UPT SMP Negeri 20 Medan adalah seperti tabel 2 berikut ini:

Tabel 2 Data Kompetensi Guru mata pelajaran kelas IX Menerapkan Model Pembelajaran Problem Based Learning (PBL) Pada Siklus 2 (Peer Teaching)

\begin{tabular}{|c|c|c|c|c|c|c|c|c|}
\hline \multirow{2}{*}{ No. } & \multicolumn{5}{|c|}{ Aspek Penilaian } & \multirow{2}{*}{ Jlh } & \multirow{2}{*}{ Nilai } & \multirow{2}{*}{ Keterangan } \\
\hline & 1 & 2 & 3 & 4 & 5 & & & \\
\hline 1 & 3 & 3 & 2 & 2 & 3 & 13 & 65 & Baik \\
\hline 2 & 2 & 2 & 1 & 2 & 2 & 9 & 45 & Cukup \\
\hline 3 & 3 & 3 & 2 & 2 & 2 & 12 & 60 & Cukup \\
\hline 4 & 2 & 2 & 1 & 2 & 2 & 9 & 45 & Cukup \\
\hline 5 & 2 & 3 & 2 & 2 & 3 & 12 & 60 & Cukup \\
\hline
\end{tabular}


Journal of Education and Teaching Learning (JETL) 2019

Vol. 1, No. 3, 41-55

Journal Homepage: http://pusdikra-publishing.com/index.php/jetl

\begin{tabular}{|c|c|c|c|c|c|c|c|c|}
\hline 6 & 2 & 2 & 2 & 2 & 3 & 11 & 55 & Cukup \\
\hline 7 & 2 & 2 & 2 & 2 & 2 & 10 & 50 & Cukup \\
\hline 8 & 2 & 2 & 2 & 3 & 2 & 11 & 55 & Cukup \\
\hline 9 & 2 & 2 & 2 & 2 & 2 & 10 & 50 & Cukup \\
\hline 10 & 3 & 2 & 2 & 2 & 2 & 11 & 55 & Cukup \\
\hline 11 & 2 & 3 & 2 & 2 & 2 & 11 & 55 & Cukup \\
\hline 12 & 3 & 2 & 2 & 3 & 3 & 13 & 65 & Baik \\
\hline 13 & 2 & 2 & 3 & 2 & 3 & 12 & 60 & Cukup \\
\hline $\mathrm{J}$ & 30 & 30 & 25 & 28 & 31 & - & - & \\
\hline $\mathbf{N}$ & 46,15 & 46,15 & 38,46 & $\mathbf{4 3 , 0 8}$ & $\mathbf{4 7 , 6 9}$ & - & - & \\
\hline \multicolumn{8}{|c|}{ Jumlah Nilai Rata-rata } \\
\hline
\end{tabular}

Pada tahap refleksi siklus 2 dari hasil observasi kompetensi guru mata pelajaran kelas IX menerapkan model pembelajaran Problem Based Learning (PBL) dengan cara Peer Teaching, dari 13 (tiga belas) orang guru Workshop bagi guru mata pelajaran kelas IX UPT SMP Negeri 20 Medan peserta workshop adalah: (a) menjelaskan orientasi siswa pada masalah $=46,15 \%$ (cukup) namun masih perlu ditingkatkan, (b) mengorganisasikan siswa untuk belajar $=46,15 \%$ (cukup), namun masih perlu ditingkatkan, (c) membimbing penyelidikan individu maupun kelompok $=38,46 \%$ (kurang) maka perlu ditingkatkan, (d) mengembangkan karya dan menyajikan hasil $=43,08 \%$ (cukup) maka perlu ditingkatkan, dan (e) menganalisis dan mengevaluasi proses pemecahan masalah $=47,69 \%$ (cukup) namun masih perlu ditingkatkan. Nilai rata-rata kemampuan guru menerapkan model pembelajaran Problem Based Learning (PBL) adalah 55,38 (cukup) namun masih perlu ditingkatkan mke siklus 3 .

Pada siklus 3 peneliti menyuruh guru secara langsung kepada siswa untuk melakukan Real Teaching menerapkan model pembelajaran Problem Based Learning (PBL) sesuai dengan materi pelajaran di ruang kelas tempat tugas guru tersebut.

Data hasil observasi kompetensi guru mata pelajaran kelas IX model pembelajaran Problem Based Learning (PBL) pada pertemuan 3 (Real Teaching), dari 13 (tiga belas) orang guru Workshop bagi guru mata pelajaran kelas IX UPT SMP Negeri 20 Medan adalah seperti tabel 3 berikut ini:

Tabel 3 Data Kompetensi Guru mata pelajaran kelas IX Menerapkan Model Pembelajaran Problem Based Learning (PBL) Pada Siklus 3 (Real Teaching)

\begin{tabular}{|c|c|c|c|c|c|c|c|c|}
\hline \multirow{2}{*}{ No. } & \multicolumn{5}{|c|}{ Aspek Penilaian } & \multirow{2}{*}{ Jlh } & \multirow{2}{*}{ Nilai } & \multirow{2}{*}{ Keterangan } \\
\hline & 1 & 2 & 3 & 4 & 5 & & & \\
\hline 1 & 5 & 5 & 4 & 5 & 5 & 24 & 96 & Sangat Baik \\
\hline 2 & 4 & 4 & 4 & 4 & 4 & 20 & 80 & Baik \\
\hline 3 & 5 & 5 & 4 & 4 & 5 & 23 & 92 & Sangat Baik \\
\hline
\end{tabular}


Journal of Education and Teaching Learning (JETL) 2019

Vol. 1, No. 3, 41-55

Journal Homepage: http://pusdikra-publishing.com/index.php/jetl

\begin{tabular}{|c|c|c|c|c|c|c|c|c|}
\hline 4 & 4 & 4 & 3 & 4 & 4 & 19 & 76 & Baik \\
\hline 5 & 5 & 4 & 4 & 4 & 4 & 21 & 84 & Sangat Baik \\
\hline 6 & 4 & 4 & 4 & 4 & 4 & 20 & 80 & Baik \\
\hline 7 & 5 & 5 & 4 & 4 & 5 & 23 & 92 & Sangat Baik \\
\hline 8 & 4 & 4 & 4 & 4 & 4 & 20 & 80 & Baik \\
\hline 9 & 4 & 4 & 3 & 4 & 4 & 19 & 76 & Baik \\
\hline 10 & 5 & 5 & 4 & 4 & 4 & 22 & 88 & Sangat Baik \\
\hline 11 & 4 & 4 & 4 & 4 & 4 & 20 & 80 & Baik \\
\hline 12 & 4 & 4 & 4 & 4 & 4 & 20 & 80 & Baik \\
\hline 13 & 5 & 5 & 4 & 4 & 5 & 23 & 92 & Sangat Baik \\
\hline $\mathrm{J}$ & 58 & 57 & 50 & 53 & 56 & - & - & - \\
\hline $\mathbf{N}$ & 89,23 & 87,69 & 76,92 & 81,53 & 86,15 & - & - & \\
\hline \multicolumn{8}{|c|}{ Jilai Rata-rata } \\
\hline \multicolumn{8}{|c|}{} \\
\hline \multicolumn{8}{|c|}{}
\end{tabular}

Pada tahap refleksi siklus 3 dari hasil observasi kompetensi guru mata pelajaran kelas IX menerapkan model pembelajaran Problem Based Learning (PBL) dengan cara Real Teaching, dari 13 (tiga belas) orang guru Workshop bagi guru mata pelajaran kelas IX UPT SMP Negeri 20 Medan adalah: (a) mempersiapkan alat/bahan/materi pembelajaran = 89,23\% (sangat baik), (b) membentuk kelompok dan memberi penomoran (numbering) $=87,69 \%$ (sangat baik), (c) memotivasi siswa agar mampu mengajukan pertanyaan (questioning) $=76,92 \%$ (baik), (d) memotivasi siswa agar ada kemampuan berpikir bersama (head together) $=81,53 \%$ (sangat baik), dan (e) memotivasi siswa agar dapat memberikan jawaban (answering) $=86,15 \%$ (sangat baik). Nilai rata-rata kemampuan guru menerapkan model pembelajaran Problem Based Learning (PBL) adalah 84,31 (sangat baik). Sesuai dengan hasil refleksi, maka peneliti memutuskan bahwa menerapkan model pembelajaran Problem Based Learning (PBL) ini sudah memenuhi ketuntasan minimal, maka tidak perlu dilanjutkan ke pertemuan berikutnya.

Data hasil angket sikap guru mata pelajaran kelas IX menerapkan model pembelajaran Problem Based Learning (PBL) dari 13 (tiga belas) orang guru Workshop bagi guru mata pelajaran kelas IX UPT SMP Negeri 20 Medan adalah seperti tabel 4 berikut ini:

Tabel 4. Data Sikap Guru Menerapkan Model Pembelajaran Problem

Based Learning (PBL) Melalui Musyawarah Guru Mata Pelajaran

(MGMP) Kelas IX di UPT SMP Negeri 20 Medan

\begin{tabular}{|c|c|c|c|c|c|}
\hline \multirow{2}{*}{ No. } & \multicolumn{4}{|c|}{ Aspek Sikap } & \multirow{2}{*}{ إ } \\
\hline & 1 & 2 & 3 & 4 & \\
\hline 1 & 5 & 5 & 5 & 5 & 20 \\
\hline
\end{tabular}


Journal of Education and Teaching Learning (JETL) 2019

Vol. 1, No. 3, 41-55

Journal Homepage: http://pusdikra-publishing.com/index.php/jetl

\begin{tabular}{|c|c|c|c|c|c|c|}
\hline 2 & 4 & 4 & 5 & 5 & 18 & \\
\hline 3 & 5 & 5 & 5 & 5 & 20 & \\
\hline 4 & 4 & 4 & 5 & 5 & 18 & \\
\hline 5 & 5 & 5 & 5 & 5 & 20 & \\
\hline 6 & 5 & 4 & 5 & 5 & 19 & \\
\hline 7 & 5 & 5 & 5 & 5 & 20 & \\
\hline 8 & 4 & 4 & 5 & 5 & 18 & \\
\hline 9 & 4 & 4 & 4 & 4 & 16 & \\
\hline 10 & 5 & 5 & 5 & 5 & 20 & \\
\hline 11 & 4 & 4 & 5 & 5 & 18 & \\
\hline 12 & 4 & 4 & 4 & 5 & 17 & \\
\hline 13 & 5 & 5 & 5 & 5 & 20 & \\
\hline & & & & & & \\
\hline Jumlah & $\mathbf{5 9}$ & $\mathbf{5 8}$ & $\mathbf{6 3}$ & $\mathbf{6 4}$ & $\mathbf{2 4 4}$ & \\
\hline Nilai maximal & $\mathbf{6 5}$ & $\mathbf{6 5}$ & $\mathbf{6 5}$ & $\mathbf{6 5}$ & $\mathbf{2 6 0}$ & \\
\hline Presentase (\%) & $\mathbf{9 0 , 7 7}$ & $\mathbf{8 9 , 2 3}$ & $\mathbf{9 6 , 9 2}$ & $\mathbf{9 8 , 5 7}$ & $\mathbf{9 8 , 4 6}$ & \\
\hline
\end{tabular}

98,46\% (sagat setuju) guru menerapkan Model Pembelajaran Problem Based Learning (PBL) Melalui Musyawarah Guru Mata Pelajaran (MGMP) Kelas IX di UPT SMP Negeri 20 Medan yang dilakukan oleh peneliti, kerena kompetensi mereka meningkat

\section{Simpulan dan Saran}

\section{Simpulan}

Berdasarkan hasil penelitian pada Bab IV, ada beberapa simpulan dalam penelitian tindakan sekolah ini yaitu: 1). Kompetensi guru Workshop bagi guru mata pelajaran kelas IX UPT SMP Negeri 20 Medan menerapkan model pembelajaran Problem Based Learning (PBL) meningkat setelah mengikuti Workshop bagi Guru Mata Pelajaran Kelas IX di UPT SMP Negeri 20 Medan. 2). Untuk dapat mengetahui upaya meningkatkan kompetensi guru menerapkan model pembelajaran Problem Based Learning (PBL), maka dapat dilakukan Workshop bagi Guru Mata Pelajaran Kelas IX dengan strategi: a) Modelling, b) Feer Teaching, dan c) Real Teaching. Modelling, maksudnya adalah peneliti menjadi model untuk menerapkan model pembelajaran Problem Based Learning (PBL). Melalui Modelling ini, guru mata pelajaran kelas IX pada Workshop bagi Guru Mata Pelajaran Kelas IX di UPT SMP Negeri 20 Medan mudah memahami cara menerapkan model pembelajaran Problem Based Learning (PBL) maka peneliti menjadi model untuk memberikan contoh. Setelah melalui Modelling maka ditingkatkan kompetensi guru melakukan Peer Teaching. Peer Teaching, maksudnya adalah peneliti menyuruh guru secara bergiliran untuk melakukan Peer Teaching. Melalui Peer Teaching ini para guru mata pelajaran kelas IX pada Workshop bagi Guru Mata 
Journal of Education and Teaching Learning (JETL) 2019

Vol. 1, No. 3, 41-55

Journal Homepage: http://pusdikra-publishing.com/index.php/jetl

Pelajaran Kelas IX di UPT SMP Negeri 20 Medan dapat praktek menerapkan model pembelajaran Problem Based Learning (PBL). Setelah guru melakukan Peer Teaching menerapkan model pembelajaran Problem Based Learning (PBL), maka ditingkatkan kompetensinya ke Real Teaching. Real Teaching, maksudnya guru menerapkan model pembelajaran Problem Based Learning (PBL) di ruang kelas tempat guru tersebut mengajar. 3). Nilai rata-rata kompetensi guru Workshop bagi Guru Mata Pelajaran Kelas IX UPT SMP Negeri 20 Medan dalam menerapkan model pembelajaran Problem Based Learning (PBL) yaitu siklus 1 (Modelling) adalah 28,08, siukkus 2 (Peer Teaching) adalah 55,38, dan siklus 3 (Real Teaching) adalah 84,31. terdiri dari 3 (tiga) siklus. 4). Nilai rata-rata kompetensi Workshop bagi guru mata pelajaran kelas IX UPT SMP Negeri 20 Medan dalam dalam menerapkan model pembelajaran Problem Based Learning (PBL), meningkat dari siklus 1 yaitu ke siklus 3 yaitu: 28,08 menjadi 84,31 . Peningkatan nilai rata-rata kompetensi guru: $84,31 \%-28,08 \%=$ 56,23\%. 5). Guru pada Workshop bagi guru mata pelajaran kelas IX UPT SMP Negeri 20 Medan 98,46\% (sangat setuju) menerapkan model pembelajaran Problem Based Learning (PBL) melalui Workshop bagi Guru Mata Pelajaran Kelas IX di UPT SMP Negeri 20 Medan yang dilakukan oleh peneliti, karena kompetensi mereka meningkat.

\section{Saran}

Berdasarkan simpulan penelitian ini, dapat diberikan beberapa saran: 1). Agar semua guru mata pelajaran kelas VII dan kelas VIII juga dapat menerapkan model pembelajaran Problem Based Learning (PBL) dalam menyajikan materi pelajaran sehingga materi pelajaran semakin mudah dimengerti oleh siswa. 2). Agar semua kepala UPT SMP dapat memfasilitasi guru mata pelajaran menerapkan model pembelajaran Problem Based Learning (PBL) melalui workshop bekerja sama dengan pengawas sekolah. 3). Agar semua pengawas sekolah dapat membimbing guru menerapkan model pembelajaran Problem Based Learning (PBL) melalui Workshop bagi Guru yang difasilitasi oleh kepala sekolah.

\section{Daftar Pustaka}

Arikunto, S., (2006), Prosedur Penelitian Suatu Pendekatan Praktik, Rineka Cipta, Jakarta.

Arikunto, S., (2009), Dasar-Dasar Evaluasi Pendidikan, Bumi Aksara, Jakarta.

Aryulina, D., (2007), Biologi, Grafindo, Jakarta.

Dasna, I.W. dan S, (2007), Pembelajaran Berbasis Masalah (Problem Based Learning (PBL) ), http:/pbl.htm (Diakses pada tanggal 30 januari 2013). 
Journal of Education and Teaching Learning (JETL) 2019

Vol. 1, No. 3, 41-55

Journal Homepage: http://pusdikra-publishing.com/index.php/jetl

Dimyati, (2002), Belajar dan Pembelajaran. Rineka Cipta, Jakarta.

Djamarah. (2006). Strategi Belajar Mengajar. Rineka Cipta, Jakarta.

Fadillah, H, (2010), http://putracenter.net/2009/Oli'07/pencemarati-udaradampak-dan-solusinya/

(Diakses pada tanggal 6 januari 2013)

Kunandar, (2008), Langkah Mudah Penelitian Tindakan Kelas Sebagai Pengemhangan Profesi Guru. Rajawali Press : Jakarta

Kunandar, (2009), Guru Profesional Implementasi Kurikulum Tingkat Satuan Pendidikan (KTPS) dan

Sukses Dalam Sertifikasi Guru, Raja Grafindo Persada, Jakarta.

Jelantik, (2009), pengertian Hasil Belajar, http://www.depdiknas.go.id/. (Diakses pada tanggal 2 februari 2013).

Nasution, S., (2004), Didaktik Asas-asas Mengajar, Bumi Aksara, Jakarta.

Pratiwi, D.A, dkk. 2007, Biologi SMA jilid 2 untuk Kelas IX, Jakarta Penerbit Erlangga.

Purwanto, N, (2006), Psikologi Pendidikan, Rosdakarya, Bandung.

Sagala, S., 2003, Konsep dan Makna Pembelajaran Untuk Mebantu Memecahkan Problematika Belajar dan Mengajar, Bandung Alfabeta.

Sanjaya, W., (2006), Strategi Pembelajaran Berorientasi Standar Proses Pendidikan, Penerbit Kencana Prenada Media Group, Jakarta.

Slameto, (2003), Belajar dan Faktor-Faktor Yang Mempengaruhinya, Rineka Cipta, Jakarta.

Sudjana, N., 2009, Penilaian Proses Hasil Belajar Mengajar, Bandung PT. Remaja Rosdakarya

Syamsuri, (2007), Biologi, Erlangga, Jakarta

Riyanto, Y., (2008), Paradigma Baru Pembelajaran, Kencana Perdana Media Group, Jakarta 